\title{
Obesity and infection - the challenge of tropical medicine
}

\author{
Obesidade e infeção - o desafio da medicina tropical
}

\author{
Anabela Mota-Pinto \\ Faculdade de Medicina da Universidade de Coimbra, Rua Larga \\ 3004-504 Coimbra, Portugal \\ Email: apinto@uc.pt
}

Este artigo foi apresentado como comunicação oral no seminário "Segurança Alimentar e Nutricional na Medicina Tropical caminhos comuns na CPLP", realizado como encontro satélite do $3^{\circ}$ Congresso Nacional de Medicina Tropical, no dia 17 de

Abril de 2015

\begin{abstract}
The World Health Organization currently considers obesity a worldwide epidemic. A perspective of the past considered overeating and a sedentary lifestyle as main factors of this major public health problem. However, other risk factors can be associated, such as heredity, sleep disorders and the action of microbial agents.

Regarding the association of obesity with infection, it appears that some microorganisms such as viruses, bacteria, parasites and tropical microbial agents (e.g. chagas disease and cutaneous leishmaniasis) are markedly related to human obesity, and it has been shown that obese individuals have an altered response to infections. The mechanism behind the adipogenic action of these microorganisms varies from the effect on the central nervous system, to the modification of metabolism of adipose tissue. Obesity and the consequent expansion of adipose tissue alter imune system function, which may lead to an increased susceptibility to infection by various microorganisms. In summary, there is a close interrelationship between the adipose tissue, the immune-inflammatory response and infection, being conceivable that in response to certain infections, adipose tissue expands and reacts in a similar way to the expansion of immune system cells. Obesity decreases the immune response of adipose tissue, which modifies the patocronia of infections.
\end{abstract}

Keywords: Obesity; Infection; Adipokines

\section{Resumo}

A obesidade é atualmente considerada pela Organização Mundial de Saúde uma epidemia mundial. Numa perspetiva do passado, consideram-se como principais fatores deste grande problema de saúde pública, o comer em excesso e o sedentarismo. No entanto, outros fatores de risco se podem associar, como é o caso da hereditariedade, dos distúrbios do sono e a ação de agentes microbianos.

Em relação à associação da obesidade com a infeção, verifica-se por um lado que alguns micro-organismos como os vírus, bactérias, parasitas e agentes microbianos tropicais (como os da Doença de Chagas e da Leishmaniose cutânea) estão marcantemente relacionados com a obesidade humana, por outro lado está demonstrado que os indivíduos obesos apresentam uma resposta alterada às infeções. O mecanismo subjacente à ação adipogénica destes micro-organismos varia, desde o efeito sobre o sistema nervoso central, à modificação do metabolismo do tecido adiposo. A obesidade e a consequente expansão do tecido adiposo, por sua vez, alteram a função imunitária, que pode conduzir a um aumento da suscetibilidade à infeção por diferentes micro-organismos. Numa visão global, existe uma inter-relação estreita entre o tecido adiposo, a resposta imuno-inflamatória e a infeção, sendo concebível que em resposta a certas infeções, o tecido adiposo se expanda e responda de uma forma semelhante à expansão das células do sistema imunitário. A resposta imunitária diminuída do tecido adiposo na obesidade modifica a patocronia das infeções.

Palavras-chave: Obesidade; infeção; adipocinas 
Obesity is a condition in which the excessive fat accumulation clearly increases the morbidity and mortality for multiple adverse health effects, such as the onset of cardiovascular disease, type 2 diabetes mellitus, musculoskeletal disease, respiratory disease, and certain types of cancers. Additionally, by modifying the immune-inflammatory response, it is also associated with an imbalanced response to infection.

As stated by the World Health Organization the problem of overweight (persons) and obesity is an epidemic that the world is currently experiencing, and, according to a traditional view, is due to an excess of food intake and decrease of physical activity. However, additional factors must be considered, such as heredity, endocrine disorders, sleep disorders, and the action of certain microorganisms (Figure 1) [1].
A obesidade é uma condição na qual a acumulação de gordura em excesso, aumenta claramente a morbilidade e mortalidade pelos múltiplos efeitos adversos para a saúde, como por exemplo o aparecimento de doenças cardiovasculares, diabetes mellitus tipo 2, patologia músculo-esquelética, doenças respiratórias, certos tipos de neoplasias e adicionalmente, ao modificar a resposta imuno-inflamatória, está também associada a um desequilíbrio de resposta à infeção.

O problema do excesso de peso e obesidade, uma epidemia que o mundo está atualmente a vivenciar como foi declarado pela Organização Mundial de Saúde, deve-se, segundo uma visão tradicional, ao excesso de consumo alimentar e a uma diminuição da atividade física. No entanto, fatores adicionais têm que ser considerados, como a hereditariedade, alterações endócrinas, distúrbios do sono e a ação de alguns microrganismos (Figura 1) [1].

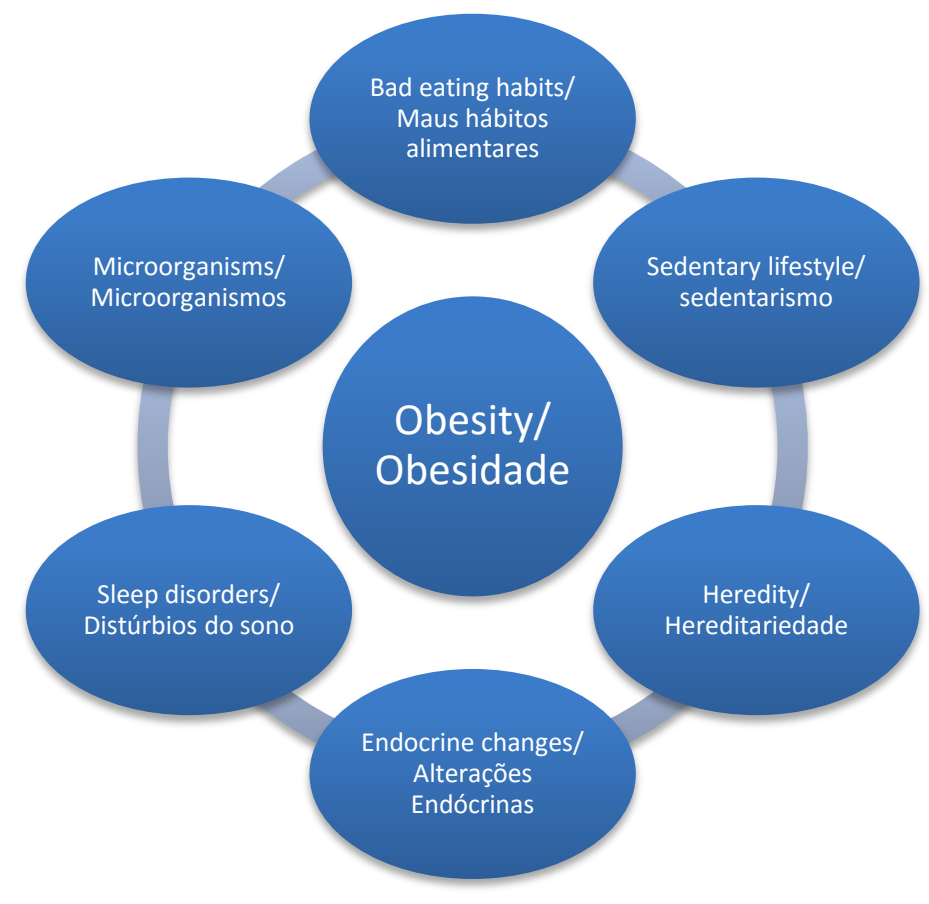

Figure 1/ Figura 1 - Multifactorial etiology of obesity

Etiologia Multifatorial da Obesidade

Adipose tissue is a complex organ with endocrine and metabolically active functions. In addition to preadipocytes and adipocytes, adipose tissue is composed of many cell types, including vascular stromal cells and connective tissue, nerve tissue, immune cells and endothelial cells. Together, these cells behave as an integrated interactive network, responding to afferent signals of the hormonal and the central nervous system, expressing and secreting factors with important en-
O tecido adiposo é um órgão complexo, com funções endócrinas e metabolicamente ativo. Para além de adipócitos e pré-adipócitos, o tecido adiposo é composto por vários tipos de células, incluindo células vasculares do estroma e tecido conjuntivo, tecido nervoso, células do sistema imunitário e células endoteliais, que em conjunto funcionam como uma rede interativa integrada, respondendo a sinais aferentes do sistema hormonal e do sistema nervoso central, expressa e segrega fatores 
docrine functions and metabolizing steroid hormones and glucocorticoids. The important endocrine function of adipose tissue is emphasized by the adverse metabolic consequences, either for its excess or deficiency, explaining the biological mechanisms between excess body fat and the relationship of metabolic disorders such as diabetes and cardiovascular disease. This plurality allows adipose tissue to be involved in a range of biological processes, including three major areas - energy metabolism, endocrine function and immune function (Figure 2) [2]. com funções endócrinas importantes e metaboliza hormonas esteroides e glicocorticóides. A função endócrina importante do tecido adiposo é enfatizada pelas consequências metabólicas adversas quer pelo seu excesso quer pela sua deficiência, explicando os mecanismos biológicos da relação entre um excesso de gordura corporal e perturbações metabólicas, diabetes mellitus, e doença cardiovascular. Esta pluralidade, permite-lhe estar envolvido numa variedade de processos biológicos que incluem três grandes áreas - o metabolismo energético, a função endócrina e a função imunitária (Figura 2) [2].

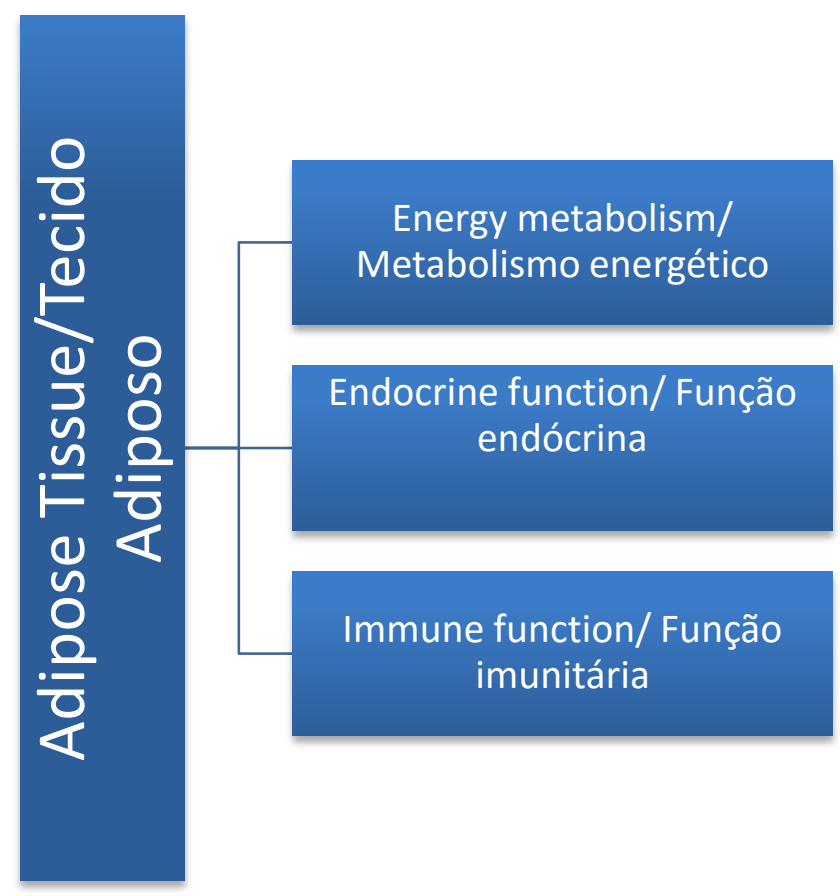

Figure 2/ Figura 2 - The adipose tissue and the homeostasis of the human body

\section{O Tecido Adiposo e a Homeostasia do Organismo Humano}

Adipose tissue is directly and actively involved in the control of body weight and energy balance by the secretion of a large number of molecules, such as leptin, adiponectin, complement factors, inhibitor-1 of plasminogen activator, proteins of the renin angiotensin system, resistin and several cytokines. This multiplicity of actions supports the theory that the adipocyte is not only a deposit of "fat". Instead, it actively contributes to the homeostasis of human body [2]. The role of adipose tissue is so important in the physiology and pathophysiology of obesity related diseases that research about this subject has been increasing in the last decade [3, 4]. Recent data has pointed to an association between obe-
Direta e ativamente o tecido adiposo está envolvido no controlo do peso corporal e no balanço de energia através da secreção de um grande número de moléculas como a leptina, adiponectina, fatores do complemento, inibidor-1 do ativador de plasminogénio, proteínas do sistema renina-angiotensina, resistina e várias citocinas. Esta multiplicidade de ações suporta a teoria de que o adipócito, não é apenas um depósito de "gordura", mas pelo contrário contribui ativamente para a homeostasia do organismo humano [2]. É de tal forma importante o papel de tecido adiposo na fisiologia e fisiopatologia das doenças relacionadas direta ou indiretamente com a obesidade, que este assunto tem sido cada vez mais estudado e demonstrado $[3,4]$. 
sity and infectious diseases, in particularly with tropical infections. Although the mechanism underlying these findings is not well established, a number of potential factors seem to be involved.

It is therefore imperative to globaly understand what influences the adipose tissue enlargement and the consequences of this expansion. Research has demonstrated dynamic interactions between adipose tissue and various microorganisms. These interactions can be identified in three different aspects: the role of adipose tissue in the immuno-inflammatory response, the effect of microorganisms in the expansion of adipose tissue, and the result of the expansion of adipose tissue in response to microbial infection (figure 3) [1].
Dados recentes apontam para uma associação entre obesidade e doenças infeciosas, nomeadamente as tropicais. Embora o mecanismo subjacente a estas conclusões não esteja bem estabelecido, uma série de potenciais fatores parecem estar envolvidos.

É pois imperativo, compreender de forma abrangente quais as consequências da expansão do tecido adiposo, e o que influencia a sua expansão. A investigação tem demonstrado interações dinâmicas entre o tecido adiposo e vários micro-organismos. Estas interações podem ser identificadas em três diferentes aspetos: o papel de tecido adiposo na resposta imuno-inflamatória, o efeito dos micro-organismos na expansão do tecido adiposo, e o resultado da expansão do tecido adiposo na resposta à infeção microbiana (figura 3) [1].

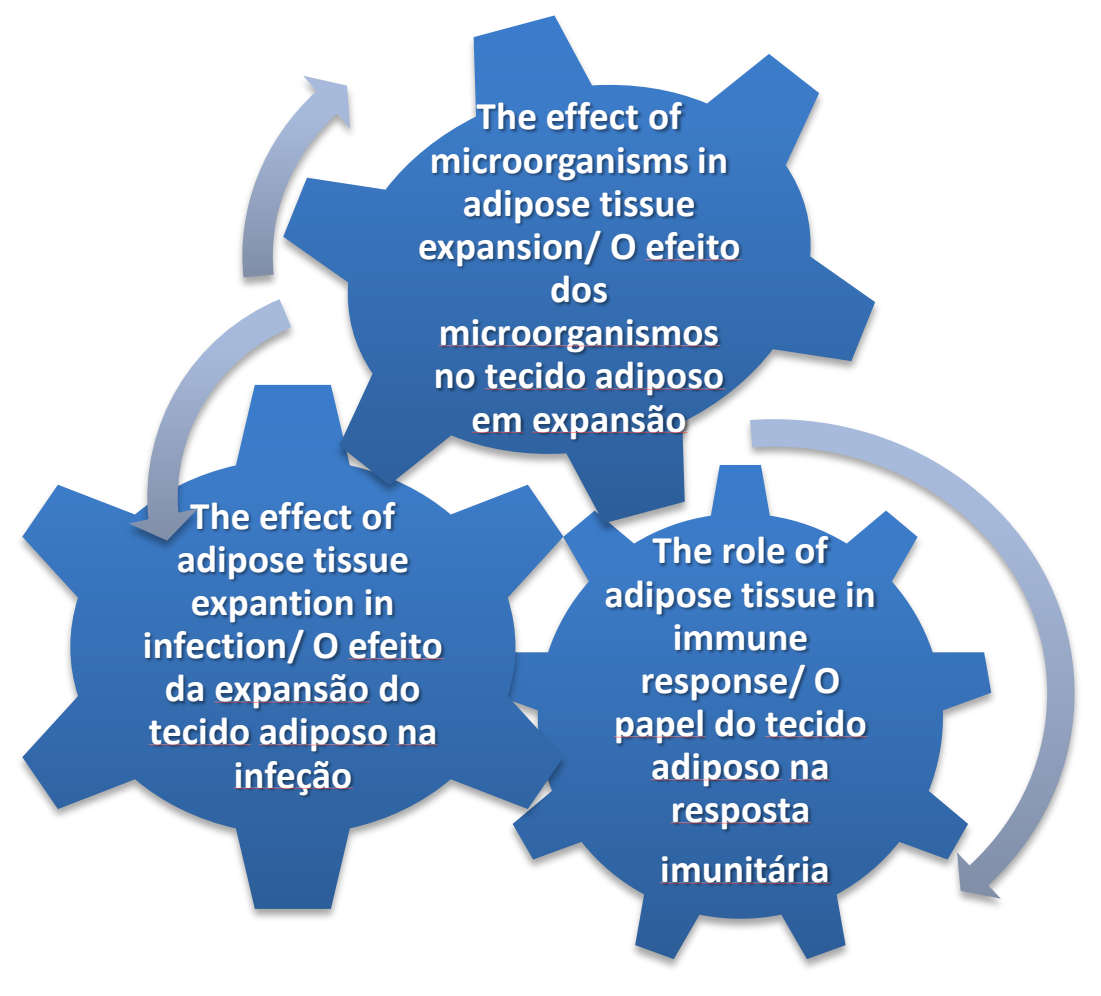

Figure 3/ Figura 3 - Obesity and infection - "Interactions"

Obesidade e infeção - "Interações"

The immuno-inflammatory function of adipose tissue can be attributed to immune system cells that compose adipogenic cells and also to their precursors (stromal vascular cells, preadipocytes and adipocytes). Immature hematopoietic cells are a part of adipose tissue, suggesting that this tissue is a site for the formation and maturation of immune cell precursors. The immune cells present in the adipose tissue are involved in combating infection and they also contribute to angiogenesis, to cell removal by apoptosis, and to extracellular matrix remodeling [5].
A função imuno-inflamatória do tecido adiposo, pode ser atribuída às células do sistema imunitário que o compõem e às células adipogénicas e seus precursores (células vasculares do estroma, pré-adipócitos e adipócitos). No tecido adiposo estão presentes células hematopoiéticas imaturas, o que sugere que este tecido seja um local para a formação e maturação de precursores de células imunitárias. As células do sistema imunitário presentes no tecido adiposo participam no combate à infeção e contribuem para a angiogénese, para a re- 
In addition to the adipose tissue immune cells, there are signs that even preadipocytes and adipocytes are likely to interact with invading microorganisms. The adipocyte lineage cell seems to share an embryonic origin with the monocyte/macrophages line, and the synthesis of numerous inflammatory cytokines such as tumor necrosis factor $\alpha$ (TNF- $\alpha$ ) are also susceptible to activation by lipopolysaccharide [6,7].

Moreover, it was found that obesity is associated with increased adipose tissue infiltration by macrophages. Obesity also induces a macrophage phenotypic deviation, towards a M1 type, which predominantly secrete pro-inflammatory and inflammatory molecules, such as TNF- $\alpha$ and interleukin-6 (IL-6) that contribute to an insulin resistance. The monocyte chemoattractant protein-1 (MCP-1), a chemokine that recruits monocytes to sites of inflammation, is expressed and secreted by adipose tissue, which enhances the important role of adipocytes and stromal cells in the chemotaxis of macrophages $[2,4,8]$.

The scientific interest in the biology of white adipose tissue (WAT) has increased since the discovery of leptin in 1994.

Research has shown that adipokines (the term generally applied to biologically active substances found in the WAT adipocytes) are produced mainly in adipocytes, and can be considered as a vehicle of communication between exogenous factors, such as nutrition and lifestyle, and endogenous factors associated with obesity through the molecular pathways, that lead to metabolic syndrome, inflammation and infection.

In this text we will address three adipokines, produced mainly by adipocytes, with a striking role in the area of immune-inflammatory response and consequently in infection.

Leptin belongs to the class I cytokine superfamily, and the circulating levels are directly correlated with the WAT. Leptin reduces the need of food intake. It increases energy consumption by inducing anorectic factors and suppressing orexigenic neuropeptides [3]. Leptin acts on the immune-inflammatory system and its proinflammatory effects include cell modulation of monocyte/macrophages, neutrophils, basophils, eosinophils, natural killer and dendritic cells by increasing pro-inflammatory cytokines, such as IL-1 and IL6. Studies with leptin in mice showed that this peptide modifies $\mathrm{T}$ differentiation towards a proinflammatory Th1 response [3]. A deficiency in leptin and its receptor in mice revealed that these (deficient) animals are less prone to develop inflammatory diseases [1].

Adiponectin was discovered by approximately the same time as leptin, but only recently has been recognized moção celular por apoptose ou remodelação de matriz extracelular [5].

Adicionalmente às células imunitárias do tecido adiposo, surgem indícios que mesmo os pré-adipócitos e adipócitos são suscetíveis de interagir com os micro-organismos invasores. As células da linhagem dos adipócitos parecem partilhar uma origem embrionária com a linhagem de monócitos/macrófagos e com a síntese de numerosas citocinas inflamatórias, tais como o fator de necrose tumoral $\alpha(\mathrm{TNF}-\alpha)$, sendo também sensíveis à ativação pelo lipopolissacarideo $[6,7]$.

Paralelamente, verifica-se que a obesidade está associada ao aumento da infiltração do tecido adiposo por macrófagos. A obesidade também induz um desvio fenotípico destas células, no sentido de uma ativação dos macrófagos do tipo M1, que segregam moléculas pró-inflamatórias e inflamatórias como o TNF- $\alpha$ e a interleucina-6 (IL-6), que contribuem para uma insulina resistência. A proteína "Monocyte chemoattractant protein-1" (MCP-1), uma quimiocina que recruta monócitos para os sítios de inflamação, é expressa e secretada pelo tecido adiposo, o que reforça o papel importante dos adipócitos e provavelmente das células do estroma na quimiotaxia dos macrófagos $[2,4,8]$.

$\mathrm{O}$ interesse científico na biologia do tecido adiposo branco (TAB) aumentou muito, desde 1994 com a descoberta da leptina. A investigação tem evidenciado, que as adipocinas (termo geralmente aplicado a substâncias biologicamente ativas encontradas nos adipócitos do TAB), são produzidas predominantemente nos adipócitos, e podem ser consideradas como um veículo de comunicação entre os fatores exógenos relacionados com a obesidade, tais como a nutrição e estilo de vida, e os fatores endógenos através das vias moleculares que conduzem ao síndrome metabólico, à inflamação e também à infeção. Por serem produzidas maioritariamente pelos adipócitos e pela sua importância na resposta imuno-inflamatória e consequentemente na resposta à infeção, iremos abordar três adipocinas com um papel marcante nestas duas áreas.

A leptina, pertence à superfamília de citocinas de classe I, a sua concentração na circulação está diretamente correlacionada com o TAB e atua diminuindo a necessidade de ingestão de alimentos, aumentando o consumo de energia através da indução de fatores anorexígenos e suprimindo os neuropeptídeos orexigenos [3]. A leptina atua no sistema imunoinflamatório e os seus efeitos proinflamatórios incluem a modulação de monócitos/ macrófagos, neutrófilos, basófilos, eosinófilos, células "natural Killer", células dendríticas, e o aumento de citocinas pró-inflamatórias como a IL-1, IL-6. Em ratinhos a diferenciação $\mathrm{T}$ faz-se no sentido de uma 
its role on innate and adaptive immunity. Adiponectin interferes with the function of macrophages by inhibiting phagocytic activity and the synthesis of TNF and IL-6. It also decreases T-cells response, reduces B-cell lymphopoiesis, and induces the production of anti-inflammatory cytokines, such as interleukin-10 (IL-10) and the receptor interleukin-1 (IL-1RA) by monocytes/ macrophages and dendritic cells. It increases fatty acid oxidation and reduces the synthesis of glucose in the liver. These actions give an important role to adiponectin in protection against obesity and obesity related diseases, as well as anti-inflammation [3].

Resistin was named by the apparent induction of insulin resistance in mice, but it seems that this action happens only in animals. It is suggested that resistin is involved in the inflammatory response, once its secretion is induced in substantial amounts by mononuclear cells. Resistin levels are positively correlated with other markers of inflammation, such as the soluble receptor of tumor necrosis factor (TNF-R) type II and lipoprotein-associated phospholipase A2. Moreover, it was described that the lipopolysaccharide (LPS) induces the gene expression of resistin in macrophages through a cascade that involves the secretion of proinflammatory cytokines, and in peripheral blood, mononuclear cells resistin synthesis seems both to induce and be induced by IL-6 and TNF [3].

A striking aspect of adipokines and its mediators is its pleiotropic role, by action or absence, in various immuno-inflammatory diseases: insulin resistance, rheumatoid arthritis, inflammatory bowel disease, sepsis, and encephalomyelitis infection.

The ability of adipose tissue to modulate immune function links obesity to a chronic state of low-grade inflammation, since it expands adipose tissue mass. The prevalence of obesity, related with metabolic changes, is closely linked to the onset of chronic low-grade inflammation, present in adipose tissue, which severely alters the endocrine function $[4,9,10]$.

Several studies have shown that certain infections may promote the development of obesity, which are scientifically termed as "infectobesity" [11]. The first study in "infectobesity" was published in 1982. An obesity syndrome was observed in a number of mice infected with canine distemper virus [12]. Since then, microorganisms related to tropical diseases, animal and human viruses, bacteria and parasites, have been reported to induce obesity in models using insects, chickens, rodents, and non-human primates $[13,14]$. The association with human obesity is studied in several microbial agents, such as Trypanosoma cruzi [13], Leishmania [15], Chlamydia pneumoniae [16], Helicobacter pylori [17], adenoviruses [18, 19], herpes simplex 1 or 2, En- resposta proinflamatória do tipo Th1 [3]. A deficiência de leptina e do seu receptor em ratinhos, demonstrou a diminuição do desenvolvimento de menos patologia inflamatória neste animais [1].

A adiponectina foi descoberta aproximadamente ao mesmo tempo que a leptina, mas só recentemente foi reconhecido o seu papel relevante na imunidade inata e adaptativa. Interfere com a função dos macrófagos por inibir a atividade fagocítica e a síntese de TNF e IL-6, reduz a linfopoiese das células $\mathrm{B}$, diminui a resposta de células $T$, e induz a produção de citocinas anti-inflamatórias como a interleucina 10 (IL-10) e o recetor A da interleucina-1 (IL-1RA) por monócitos/macrófagos e células dendríticas, aumenta ainda a oxidação dos ácidos gordos e a síntese de glicose no fígado. Estas ações conferem-lhe uma atividade importante na proteção contra a obesidade e patologias relacionadas com a obesidade, assim como na anti-inflamação [3].

A resistina recebeu o seu nome, pela aparente indução de resistência à insulina em ratinhos, mas parece que esta ação acontece apenas nos animais. Sugere-se, que a resistina esteja envolvida na resposta inflamatória pela indução da sua secreção em quantidades substanciais, por células mononucleares. Os níveis de resistina estão positivamente associados com outros marcadores de inflamação, tais como o recetor do fator de necrose tumoral (TNF-R) do tipo II e a lipoproteína associada à fosfolipase A2. Além disso, foi descrito que o lipopolissacarídeo (LPS) induz a expressão do gene da resistina em macrófagos, através de uma cascata que envolve a secreção de citocinas pró-inflamatórias, e em células mononucleares do sangue periférico a síntese de resistina parece induzir e ser induzida por IL-6 e TNF [3]. Um aspeto marcante das adipocinas e dos mediadores a que dão origem, é o seu papel pleiotrópico, por ação ou ausência, em várias patologias imuno-inflamatórias: insulino-resistência, artrite reumatoide, inflamação intestinal, sepsis, encefalomielite e infeção.

Esta capacidade de modulação da função imunitária pelo tecido adiposo, confere à obesidade pela expansão deste tecido, uma relação causal com o estado inflamatório crónico de baixo-grau presente no adipócito. A prevalência da obesidade relacionada com alterações metabólicas, está estreitamente associada ao aparecimento da inflamação crónica de baixo grau, presente no tecido adiposo e que altera gravemente a função endócrina deste órgão $[4,9,10]$.

Estudos de diversos autores têm demonstrado que certas infeções podem promover o desenvolvimento de obesidade, que cientificamente têm denominado como "infectobesity" [11]. O primeiro estudo sobre "infectobesity" de que se tem conhecimento, reporta-se a 1982, em que um síndrome de obesidade foi observado em ratinhos infetados com canine distemper vírus 
terovirus and C. pneumoniae [20]. Bacterial endotoxin itself induces expansion of adipose tissue [21].

The mechanism behind the adipogenic action of these microorganisms varies from the effect on the central nervous system (canine distemper virus) to the alteration of adipose tissue metabolism (adenovirus) [14]. The only pathogens that have a causal relationship with human obesity are adenoviruses, and they seem to influence directly the adipose tissue. Among with the human adenoviruses, adenovirus 36 (Ad36) was the first virus indicated as human adipogenic. Additionally, several studies have demonstrated that approximately 60 to $100 \%$ of the Ad36 infected animals develop obesity when comparing with the uninfected animals from control group. Ad36-infected animals have approximately a 35 to $60 \%$ moderate increase in adipose tissue after four days of inoculation [22-27]. A very similar adipose tissue increase occurs in many genetic models of obesity $[18,19,28]$. In Ad36 infected animals, the major phenotypic changes include increased adiposity. However, paradoxically, they have a better metabolic profile, with decreased serum cholesterol and triglycerides, better glycemic control and less hepatic steatosis $[14,25,27,29]$. The Ad36 induces a replication and differentiation of adipose tissue resident stem / stromal and increases the accumulation of lipids in these cells [30-33]. However, as associations do not necessarily establish a causal relationship, these authors [1] strengthen three particularly important aspects, which provide the possibility of an etiologic role of Ad36 in human obesity subgroup: (1) Obesity is often associated with a poor metabolic profile, though Ad36's ability to increase adiposity and to improve the metabolic profile in animals (improved steady state serum lipid profiles and improved glucose tolerance and insulin sensitivity) is paradoxical and unusual. However, the observation of this odd phenomenon in humans that are naturally infected with Ad36 argues for a causal role for Ad36. (2) In addition to this aspect, a recent longitudinal 10-year study of over 1,400 Hispanic men and women, who were naturally infected with Ad36, showed a significant increase in adiposity and improved glycemic control, compared to not infected individuals. (3) Not all adenoviruses are adipogenic, however, for example, human adenoviruses $\mathrm{Ad} 2$ and $\mathrm{Ad} 31$ are non-adipogenic in animal models. Similarly, the natural infection of $\mathrm{Ad} 2$ and Ad31 is not associated with obesity $[1,11]$.

The ratio between tropical infections and the development promotion of obesity is studied in chagas disease, a parasitic tropical disease caused by the protozoan Trypanosoma cruzi, which affects approximately 10 million people in Latin America. Until now, it has been found that adipose tissue and adipocytes are a ma-
[12]. Desde então, micro-organismos relacionados com doenças tropicais, vírus animais e humanos, bactérias e parasitas, foram referidos como indutores de obesidade em modelos utilizando insetos, galinhas, roedores e primatas não-humanos $[13,14]$. A associação com a obesidade humana está estudada em vários agentes microbianos como o Trypanosoma cruzi [13], e a Leishmania [15], a Chlamydia pneumoniae [16], o Helicobacter pylori [17], os Adenovírus [18, 19], o Herpes simples 1 ou 2, o Enterovírus e a C. pneumoniae [20]. A endotoxina bacteriana por si só consegue induzir expansão do tecido adiposo [21].

$\mathrm{O}$ mecanismo subjacente à ação adipogénica destes micro-organismos varia, desde o efeito sobre o sistema nervoso central (canine distemper vírus), à modificação do metabolismo do tecido adiposo (adenovírus) [14]. Os adenovírus são os únicos agentes patogénicos que têm uma relação causal com a obesidade humana, e que parecem influenciar diretamente o tecido adiposo. Entre os adenovírus humanos, o adenovírus 36 (AD36) foi o primeiro vírus indicado como adipogénico humano. Vários estudos mostraram adicionalmente, que cerca de 60 a 100\% dos animais infetados com AD36 desenvolve obesidade, em comparação com o grupo controlo de animais não infetados, e que animais AD36-infetados têm cerca de 35 a $60 \%$ de aumento moderado do tecido adiposo após 4 dias da inoculação [22-27]. Este aumento de tecido adiposo é muito semelhante ao aumento que se verifica em muitos modelos genéticos de obesidade $[18,19,28]$. Nos animais infetados com AD36, as principais mudanças fenotípicas incluem maior adiposidade, no entanto e paradoxalmente apresentam um perfil metabólico melhor, com diminuição do colesterol sérico e dos triglicerídeos, melhor controlo glicémico e menos esteatose hepática [14,25,27,29]. O AD36 induz uma replicação e diferenciação de células estaminais / estroma residentes no tecido adiposo e aumenta a acumulação de lípidos nestas células [30-33]. No entanto como as associações não estabelecem necessariamente uma relação causal, estes autores [1] reforçam três aspetos particularmente importantes e que estabelecem a possibilidade de um papel etiológico do AD36 num subgrupo de obesidade humana: (1) A obesidade é geralmente associada a um mau perfil metabólico e a capacidade do AD36 para aumentar a adiposidade, mas para melhorar o perfil metabólico em animais é paradoxal e incomum. No entanto, a observação desse fenómeno peculiar em seres humanos que são naturalmente infetados com o AD36 argumenta a favor de um papel causal para AD36. (2) Para além deste aspeto, um recente estudo longitudinal de 10 anos em que se estudaram cerca de 1400 homens e mulheres hispânicos que estavam infetados com o AD36, mostrou um aumento significativo de adiposidade e um melhor controlo glicémico, em comparação com indivíduos não infetados. (3) Nem todos os adenovírus são adipogénicos, como por exemplo os adenovírus AD2 ou AD31 humanos que são não adipogenicos em modelos animais. Do mes- 
jor reservoir of $T$. cruzi that can be reactivated during immunosuppression periods. In addition, the infection of adipocytes creates an inflammatory phenotype that affect a range of metabolic pathways. It has been shown in this infection the so-called "obesity paradox", that is, a longer survival of individuals with overweight or even obese compared to lean individuals [34]. It is yet to be proven if an overweight state / obesity is a key protector of mortality in patients with chagas disease [13, 35].

The association of infection with the expansion of adipose tissue was also studied in 86 patients with cutaneous Leishmania (CL), 38 of these subjects $(11.4 \%$ of the total) were overweight or obese, being more common in women than in men ( 15 vs. $7.8 \% ; \chi^{2}=4.28$, p $<0.05)$. Obesity was more frequent in women with $\mathrm{CL}$ than in controls ( 25.6 vs. $11.7 \%, \chi 2=4.55, \mathrm{p}<0.05)$. An overweight state / obesity were also statistically more common among men with cutaneous Leishmania (14.9 vs. 5\%). The causes of body mass index (BMI) increase and an overweight state / obesity among individuals with CL are unclear. These authors question if there is a the preference of sandflies for biting weightier or obese individuals, which was also reported with exposure to malaria mosquitoes during pregnancy. Obese individuals often have high serum levels of leptin, with or without insulin resistance. Leptin also regulates the switching of subpopulations of T helper cells (Th1 / Th2), and the production of several pro and anti-inflammatory cytokines. So, further studies have to be performed to investigate possible interactions between leptin and cytokines among obese patients with cutaneous Leishmania [15].

Obesity affects both the risk of getting an infection and the end of infection once established. Possible mechanisms have been proposed of how these patients respond to infection: dysregulation of the immune system, obesity-related comorbidities (such as diabetes mellitus and atherosclerosis), and respiratory dysfunction present in most individuals with an overweight condition/ obesity, and problems to responding to therapy (Figure 4) [36].

Obesity violates the balance between adipocytes and cells of adipose immune system tissue, with a subsequent disruption of the immune system surveillance, leading, for example, to a dysregulated immune response by decreasing mediated cell response, alteration in chemotaxis and differentiation of macrophages.

This cause-effect relationship between obesity and infection remains unclear in many infectious diseases. More research is needed. Current data indicate adverse associated effects between obesity and the progression of pancreatitis and infection by $\mathrm{H} 1 \mathrm{~N} 1$ and increased risk of hospital postoperative infections. With the mo modo, a infeção natural de AD2 ou AD31 não está associada com a obesidade $[1,11]$.

A relação das infeções tropicais com a promoção do desenvolvimento de obesidade, está estudada na Doença de Chagas (DC) uma doença tropical parasitária causada pelo protozoário Trypanosoma cruzi e que afeta aproximadamente 10 milhões de pessoas na América Latina. Até à data, verificou-se que o tecido adiposo e os adipócitos são um importante reservatório do T. cru$z i$, que pode ser reativado durante períodos de imunosupressão. Adicionalmente, a infeção dos adipócitos cria um fenótipo inflamatório que afeta uma grande variedade de vias metabólicas. Demonstrou-se ainda nesta infeção, o designado "paradoxo da obesidade" ou seja, maior sobrevida dos indivíduos com excesso de peso/ obesidade em comparação com indivíduos magros [34]. Se o excesso de peso/obesidade é um protetor determinante da mortalidade em indivíduos com doença de Chagas (DC) ainda está por se comprovar $[13,35]$. A associação da infeção com a expansão do tecido adiposo, foi também estudada na Leishmania Cutânea (LC) em 86 doentes, sendo que 38 destes indivíduos $(11,4 \%$ do total) apresentava excesso de peso/obesidade, com maior frequência entre as mulheres do que entre os homens $\left(15\right.$ vs. $\left.7,8 \% ; \chi^{2}=4,28, p<0,05\right)$. Entre as mulheres, a obesidade era mais comum em casos de LC do que nos controlos $(25,6$ vs. $11,7 \%, \chi 2=4,55, \mathrm{p}<0,05)$. Excesso de peso/obesidade era também estatisticamente mais comum, entre os homens com Leishmania cutânea $(14,9$ vs. $5 \%)$. As causas do aumento do índice de massa corporal (IMC) e a sua relação com excesso de peso/ obesidade entre indivíduos com CL não são claras. Estes autores questionam a preferência dos insetos flebotomíneos e transmissores da Leishmania por morder indivíduos obesos, como já se verificou com a exposição a mosquitos da malária durante a gravidez. Os indivíduos obesos têm frequentemente níveis elevados de leptina no soro, com ou sem resistência à insulina. Uma vez que a leptina também regula a comutação das subpopulações das células T auxiliares (Th1/Th2), e a produção de várias citocinas pró e anti-inflamatórias, mais estudos que investigam possíveis interações entre a leptina e citocinas devem ser realizada entre os pacientes obesos com Leishmania cutânea [15].

A obesidade influencia tanto o risco de contrair uma infeção, como o seu término uma vez estabelecida. A desregulação do sistema imunitário, comorbilidades relacionadas com obesidade (como a diabetes mellitus e aterosclerose), a disfunção respiratória presente na maioria dos indivíduos com excesso de peso/obesidade, e os problemas da resposta à terapêutica, têm sido propostos como possíveis mecanismos implicados na forma como estes doentes respondem à infeção (Figura 4) [36]. A obesidade viola o equilíbrio entre os adipócitos e as células do sistema imunitário no tecido adiposo, verificando-se uma perturbação subsequente do sistema de vigilância imunológica, o que conduz por exemplo, a uma resposta 
marked expansion of obesity, an increase of morbidity and mortality following infectious diseases is expected. Routinely measuring the BMI of patients during hospital consultations could potentially increase the chances of important findings in this research area. Another relevant research study is the systematic evaluation of the pharmacokinetics and pharmacodynamics of drugs in obese patients, and if this should policy be incorporated into the drug development process. imunitária desregulada por diminuição da resposta mediada por células, alteração da quimiotaxia e da diferenciação de macrófagos.

Esta relação causa-efeito entre obesidade e infeção permanece obscura em muitas doenças infeciosas, sendo necessários mais estudos. Os dados atuais indicam uma associação entre a obesidade e os efeitos adversos sobre o decurso da pancreatite e infeção pelo H1N1, e o aumento do risco de infeções pós-cirúrgicas e hospitalares. Com o aumento marcante da obesidade, podemos esperar que a mortalidade e morbilidade por doenças infeciosas aumente. A medição por rotina do IMC, em doentes na consulta hospitalar e em doentes hospitalizados poderia potencialmente, aumentar as possibilidades de conclusão nesta área de investigação. Outro estudo de investigação pertinente é a avaliação sistemática da farmacocinética e farmacodinâmica de medicamentos em doentes obesos, devendo esta diretriz ser incorporada no processo de desenvolvimento de medicamentos.

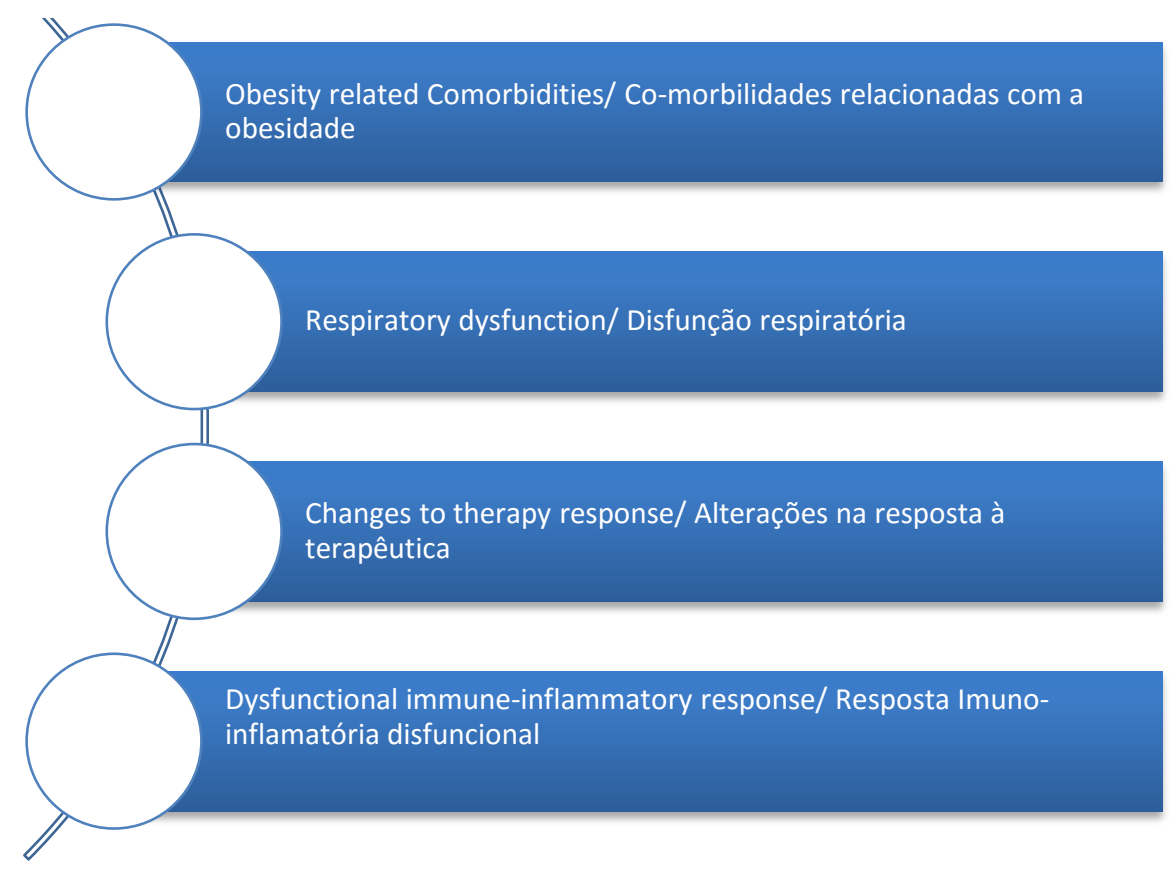

Figure 4/ Figura 4 - Adipose tissue conditions in response to infection condicionantes do efeito do tecido adiposo na resposta à infeção

\section{Conclusion}

What is the future of adipose tissue as a modulator of infection, and what is the role of tropical infections in the expansion of adipose tissue?

As the cause-effect between obesity and infection remains unclear in many infectious diseases, more studies are needed. The relation between infection of adipocytes / adipose tissue and an inflammatory phenotype

\section{Conclusão}

Qual é o futuro do tecido adiposo como modulador da infeção, e qual o papel das infeções tropicais na expansão do tecido adiposo?

Como a relação causa-efeito entre a obesidade e infeção permanece obscura em muitas doenças infeciosas, mais estudos são necessários, muito embora esteja estudado que a infeção dos adipócitos e do tecido adiposo crie 
has already been studied, as well as the maintenance this inflammatory phenotype through the decrease in adiponectin expression and PPAR- $\gamma$ (one major regulator of differentiation of adipocytes).

It is considered also important to study other microorganisms (particularly tropical infections and microbial agents), and their possible intervention in overweight / obese individuals. The exact mechanisms underlying the changes related to obesity in the course of infectious diseases are not established. Several factors may be involved, such as co-morbidities associated with obesity, immunologic effects and therapeutic response. With the rising rates of obesity, it is expected that morbidity and mortality from infection and infectious diseases will increase.

Several questions regarding this matter must be faced:

- It is interesting that the adipocyte plays a role in infection. Do the subcutaneous and intrabdominal adipose tissue act as a second line of defense? The enlargement of adipose tissue during infection acts similarly as the immune system? As an attempt to overcome the infection?

- The decreased immune response which accompanies obesity may result from a decreased immune function of adipose tissue expansion?

Moreover, we still have a lack of knowledge concerning the antimicrobial therapy response in obesity. A systematic evaluation of pharmacokinetic and pharmacodynamic studies in obese patients regarding establishment of dosage guidelines for antimicrobial drugs in obese patients is still advised.

\section{Conflict of interests}

The authors declare that there are no financial and/or personal relationships that could be viewed as presenting a potential conflict of interests. um fenótipo inflamatório que afeta uma variedade de processos, e que a redução na expressão de adiponectina e PPAR- $\gamma$ (um regulador major da diferenciação do adipócito) perpetue este fenótipo inflamatório

É igualmente importante que sejam estudados outros micro-organismos e a sua possível interferência no excesso de peso/obesidade nas várias as associações possíveis particularmente nas infeções por agentes microbianos tropicais. Os mecanismos exatos subjacentes a alterações relacionadas com a obesidade no curso de doenças infeciosas não estão estabelecidos. Vários fatores podem estar envolvidos, como por exemplo comorbilidades relacionadas com a obesidade, efeitos imunológicos e a resposta à terapêutica. Com o aumento das taxas de obesidade, podemos esperar que a mortalidade e morbilidade por infeção e doenças infeciosas possa aumentar.

Várias perguntas relativamente a este assunto se impõem:

- É intrigante o facto de o adipócito ter um papel na infeção. Será que o tecido adiposo subcutâneo e intrabdominal funciona como uma segunda linha de defesa? A expansão do tecido adiposo na infeção funciona como o sistema imunitário, numa tentativa de debelar a infeção?

- A diminuição da resposta imunitária que acompanha a obesidade, pode resultar da diminuição da função imunitária do tecido adiposo em expansão?

Por outro lado, a janela de desconhecimento da resposta à terapêutica antimicrobiana na obesidade mantem-se sendo aconselháveis estudos de avaliação sistemática da farmacocinética e farmacodinâmica em pacientes obesos, que permitam criar guidelines relativamente à dosagem de fármacos antimicrobianos nos doentes obesos.

\section{Conflito de interesses}

Os autores declaram não existir qualquer relação pessoal ou financeira que possa ser entendida como representando um potencial conflito de interesses. 


\section{References/ Referências:}

1. Hegde V, Dhurandhar NV. Microbes and obesity -interrelationship between infection, adipose tissue and the immune system. Clin Microbiol Infect. 2013; 19: 314-20.

2. Kershaw EE, Flier JS. Adipose tissue as an endocrine organ. J Clin Endocr Metab. 2004;89(6):2548-56

3. Lago F, Dieguez C, Gómez-Reino J, Gualillo O. Adipokines as emerging mediators of immune response and inflammation. Nat Clin Pract Rheumatol. 2007 Dec;3(12):716-24.

4. Clària J, González-Périz A, López-Vicario C, Rius B, Titos E. New insights into the role of macrophages in adipose tissue inflammation and fatty liver disease: modulation by endogenous omega-3 fatty acid-derived lipid mediators. Front Immun. 2001 Oct 5;2 (art 49):1-8.

5. Schipper HS, Prakken B, Kalkhoven E, Boes M. Adipose tissue-resident immune cells: key players in immunometabolism. Trends Endocrinol Metab. 2012; 23: 407-15.

6. Caspar-Bauguil S, Cousin B, Galinier A, Segafredo C, Nibbelink M, André M, et al. Adipose tissues as an ancestral immune organ: site-specific change in obesity. FEBS Lett. 2005;579(17):3487-92.

7. Saely $\mathrm{CH}$, Geiger K, Drexel H. Brown versus white adipose tissue: a mini-review. Gerontology. 2012;58(1):15-23.

8. Schäffler A, Schölmerich J. Innate immunity and adipose tissue biology. Trends Immunol. 2010;31(6):228-35

9. Tzanetakou IP, Katsilambros NL, Benetos A, Mikhailidis DP, Perrea DN."Is obesity linked to aging?": adipose tissue and the role of telomeres. Ageing Res Rev. 2012 Apr;11(2):220-9.

10. Falagas ME, Kompoti M. Obesity and infection. Lancet. Infect Dis. 2006;6(7):438-46.

11. Dhurandhar NV. A framework for identification of infections that contribute to human obesity. Lancet Infect Dis. 2011 Dec;11(12):963-9.

12. Lyons MJ, Faust IM, Hemmes RB, Buskirk DR, Hirsch J, Zabriskie JB. A virally induced obesity syndrome in mice. Science. 1982 Apr 2;216(4541):82-5.

13. Beleigoli AM, Ribeiro AL, Diniz MFH, Lima-Costa MF, Boersma E. The "obesity paradox" in an elderly population with a high prevalence of Chagas disease: The 10-year follow-up of the Bambuí (Brazil) Cohort Study of Aging. Int J Cardiol. 2013;166(2):523-6.
14. Pasarica M, Dhurandhar NV. Infectobesity: obesity of infectious origin. Adv Food Nutr Res. 2007;52:61-102.

15. Cunha DF, Cunha SFC, Nunes AG, SilvaVergara ML. Is an increased body mass index associated with a risk of cutaneous leishmaniasis?[O índice de massa corporal aumentado é associado a risco de leishmaniose cutânea?]. Rev Soc Bras Med Trop. 2009 set-out;42(5):494-5.

16. Dart AM, Martin JL, Kay S. Association between past infection with Chlamydia pneumoniae and body mass index, lowdensity lipoprotein particle size and fasting insulin. Int J Obes Relat Metab Disord. 2002 Apr;26(4):464-8.

17. Arslan E, Atilgan H, Yavasoglu I. The prevalence of Helicobacter pylori in obese subjects. Eur J Intern Med. 2009 Nov;20(7):695-7.

18. Chida D, Osaka T, Hashimoto O, Iwakura Y. Combined interleukin- 6 and interleukin-1 deficiency causes obesity in young mice. Diabetes. 2006 Apr;55(4):971-7.

19. Lång $P$, van Harmelen V, Ryden M, Kaaman M, Parini P, Carneheim C, et al. Monomeric tartrate resistant acid phosphatase induces insulin sensitive obesity. PLoS One. 2008 Mar 5;3(3):e1713.

20. Fernandez-Real JM, Ferri MJ, Vendrell J, Ricart W. Burden of infection and fat mass in healthy middle-aged men. Obesity (Silver Spring). 2007 Jan;15(1):245-52.

21. Cani PD, Amar J, Iglesias MA, Poggi M, Knauf C, Bastelica D, et al. Metabolic endotoxemia initiates obesity and insulin resistance. Diabetes. 2007 Jul;56:1761-72.

22. Dhurandhar NV. Infections and body weight: an emerging relationship? Int J Obes Relat Metab Disord. 2002 Jun;26(6):745-6.

23. Dhurandhar NV, Israel BA, Kolesar JM, Mayhew G, Cook ME, Atkinson RL. Transmissibility of adenovirus-induced adiposity in a chicken model. Int J Obes Relat Metab Disord. 2001 Jul;25(7):990-6.

24. Dhurandhar NV, Israel BA, Kolesar JM, Mayhew GF, Cook ME, Atkinson RL. Increased adiposity in animals due to a human virus. Int J Obes Relat Metab Disord. 2000 Aug;24(8):989-96.

25. Pasarica M, Shin AC, Yu M et al. Human adenovirus 36 induces adiposity, increases insulin sensitivity, and alters hypothalamic monoamines in rats. Obesity (Silver Spring). 2006 Nov;14(11):1905-13.
26. Dhurandhar NV, Whigham LD, Abbott DH, Schultz-Darken NJ, Israel BA, Bradley SM, et al. Human adenovirus Ad-36 promotes weight gain in male rhesus and marmoset monkeys. J Nutr. 2002 Oct;132(10):315560.

27. Na HN, Nam JH. Adenovirus 36 as an obesity agent maintains theobesity state by increasing MCP-1 and inducing inflammation. J Infect Dis. 2012 Mar 15;205(6):914-22.

28. Butler AA, Kesterson RA, Khong K, Cullen MJ, Pelleymounter MA, Dekoning J, et al. A unique metabolic syndrome causes obesity in the melanocortin-3 receptor-deficient mouse. Endocrinology. 2000 Sep;141(9):3518-21.

29. Krishnapuram R, Dhurandhar EJ, Dubuisson O, Kirk-Ballard H, Bajpeyi S, Butte N, et al. Template to improve glycemic control without reducing adiposity or dietary fat. Am J Physiol Endocrinol Metab. 2011 May;300(5): E779-89.

30. Vangipuram SD, Sheele J, Atkinson RL, Holland TC, Dhurandhar NV. A human adenovirus enhances preadipocyte differentiation. Obes Res. 2004 May;12(5):770-7.

31. Rogers PM, Fusinski KA, Rathod MA, Loiler SA, Pasarica M, Shaw MK, et al. Human adenovirus Ad-36 induces adipogenesis via its E4 orf-1 gene. Int J Obes (Lond). 2008 Mar;32(3):397-406.

32. Rathod MA, Rogers PM, Vangipuram SD, McAllister EJ, Dhurandhar NV. Adipogenic cascade can be induced without adipogenic media by a human adenovirus. Obesity (Silver Spring). 2009 Apr;17(4):657-64.

33. Pasarica M, Mashtalir N, McAllister EJ, Kilroy GE, Koska J, Permana P, et al. Adipogenic human adenovirus Ad-36 induces commitment, differentiation, and lipid accumulation in human adipose-derived stem cells. Stem Cells. 2008 Apr;26(4):969-78.

34. Dorner TE, Rieder A. Obesity paradox in elderly patientswith cardiovascular diseases. Int J Cardiol. 2012 Feb;155(1):56-65.

35. Nagajyothi F, Desruisseaux MS, Weiss LM, Chua S, Albanese C, Machado FS, et al. Chagas disease, adipose tissue and the metabolic syndrome. Mem Inst Oswaldo Cruz. 2009 Jul;104 Suppl 1:219-25.

36. Huttunen R, Syrjänen J. Obesity and the risk and outcome of infection. Int J Obes (lond). 2013 Mar;37(3):333-40. 